\title{
PERAN TRADISI BOTENG TUNGGUL DALAM MEMPERKUAT CIVIC CULTURE MASYARAKAT ADAT LOMBOK
}

\author{
Hamdi Abdullah Hasibuan ${ }^{1 *}$, Ernawati Simatupang ${ }^{2}$ \\ 1)2) Universitas Pendidikan Indonesia, Jawa Barat, Indonesia \\ *hamdihasibuan20@upi.edu
}

\begin{abstract}
Boteng Tunggul is one of the traditions of the East Lombok community which has unique wisdom values. This tradition is always carried out at the traditional ceremonies of the East Lombok people. In the process of implementing the Boteng Tunggul tradition, it becomes a tradition that has elements that can strengthen the civic culture in it. This research will explore the role of the boteng waiting tradition in strengthening the civic culture for the people of East Lombok. This study uses a qualitative approach to literature study methods. In this research, we will use the first data source. The data collection technique is done by using literature studies. In doing data analysis technique is done by reducing data, displaying data, and drawing conclusions. The results of the study found the entanglement of the Boteng Tunggul tradition by strengthening the civic culture in the people of East Lombok. In the stump, boteng tradition becomes a culture that can sustain citizens in it as a form of realizing the identity of the indigenous people of Lombok. This tradition is always carried out by the people of East Lombok by instilling the values of togetherness, mutual cooperation, responsibility, and tolerance in it. As well as this has illustrated that the civic culture can be strengthened by preserving and advancing this tradition.
\end{abstract}

Keywords: boteng tunggul, civic culture, indigenous peoples

\begin{abstract}
Abstrak
Boteng Tunggul merupakan salah satu tradisi dari masyarakat Lombok Timur yang memiliki nilai-nilai kearifan lokal. Tradisi ini senantiasa dilaksanakan pada upacara adat masyarakat Lombok timur. Dalam proses pelaksanaan tradisi Boteng Tunggul menjadi tradisi memiliki unsur yang dapat memperkuat civic culture didalamnya. Penelitian ini akan mengeksplorasi peran dari tradisi Boteng Tunggu untuk menguatkan civic culture bagi masyarakat Lombok Timur. Penelitian ini menggunakan pendekatan kualitatif dengan metode studi deskriptif. Dalam penelitian ini akan menggunakan sumber data pertama. Teknik pengumpulan data dilakukan dengan cara menggunakan studi literatur. Dalam melakukan teknik analisis data dilakukan dengan cara reduksi data, display data, verifikasi dan penarikan kesimpulan. Hasil penelitian menemukan keterkaitan tradisi Boteng Tunggul dengan memperkuat civic culture pada masyarakat Lombok Timur. Pada tradisi Boteng Tunggul menjadi kebudayaan yang dapat menopang warga negara didalamnya sebagai bentuk untuk mewujudkan identitas masyarakat adat Lombok. Tradisi ini selalu dilaksanakan masyarakat Lombok Timur dengan menanamkan nilai kebersamaan, gotong royong, tanggung jawab serta toleransi di dalamnya. Serta
\end{abstract}


hal ini telah menggambarkan bahwa budaya kewarganegaraan dapat diperkuat dengan tetap melestarikan dan memajukan tradisi ini.

Kata kunci: boteng tunggul, civic culture, masyarakat adat.

\section{PENDAHULUAN}

Arus globalisasi dan pesatnya perkembangan teknologi perlahan telah menggeser perhatian warga negara khususnya generasi muda untuk peduli terhadap budaya. Fenomena ini, telah membuat kebudayaan menjadi tidak berarti untuk dilestarikan.Perlahan dan secara bertahap kebudayaan mengalami difusi. Globalisasi dan perkembangan teknologi menawarkan kebudayaan yang lebih praktis. Sehingga generasi muda lebih memilih untuk berperilaku konsumtif serta individualis. Bahkan melestarikan dan memajukan kebudayaan telah dianggap sebagai perbuatan kuno dan tidak menarik.

Senada dengan Suneki (2012, hal. 309) menyatakan bahwa persoalan mengenai globalisasi yang muncul tidak dapat dihindari oleh keberadaan kebudayaan daerah, dalam hal ini terjadinya penurunan rasa cinta terhadap kebudayaan yang merupakan jati diri bangsa, erosi nilai-nilai bangsa, terjadinya akulturasi budaya. Melestarikan dan memajukan budaya bangsa merupakan tanggung jawab bersama. Tanggung jawab bersama untuk melestarikan kebudayaan telah termaktub didalam konstitusi Negara Republik Indonesia dalam Pasal 31 ayat (1) Undang-Undang Dasar Negara Republik Indonesia Tahun 1945 berbunyi "negara memajukan kebudayaan nasional Indonesia di tengah peradaban dunia dengan menjamin kebebasan masyarakat dalam memelihara dan mengembangkan nilai-nilai budayanya".

Dalam membangun Indonesia menjadi negara yang berkarakter, perlu adanya sinergitas seluruh elemen negara baik pemerintah maupun warga negara. Indonesia yang merupakan negara yang beraneka ragam suku dan budaya, tentunya perlu dimaksimalkan sebaik mungkin. Guna memperkuat keterlibatan warga negara, sekaligus peran tradisi dalam membentuk dan memperkuat kehidupan sosial serta politik bangsa. Menurut Nanggala \& Maliha (2020, hal. 2) bahwa memperkuat keterlibatan warga negara dalam proses berpolitik dan berdemokrasi perlu semangat dan kolektif semua pihak. Keterlibatan warga negara kunci dalam terselenggaranya demokrasi di Indonesia. Tentunya keterlibatan publik tersebut ditunjukkan melalui proses sosial, politik, sebagai upaya mewujudkan kesejahteraan umum.

Menurut Tilaar (Panjaitan \& Sundawa, 2016) menyatakan bahwa masyarakat dan kebudayaan akan melahirkan sebuah identitas budaya yang nantinya menjadi identitas bangsa. Identitas budaya bangsa yang menyebabkan bangsa tersebut mampu menyerap dan mengolah kebudayaan sendiri. Melalui kearifan lokal menjadi upaya untuk mempertahankan sebuah budaya dalam suatu bangsa (Prayogi \& Danial, 2016). Identitas bangsa merupakan gambaran menyeluruh dari suatu bangsa. Keseluruhan nilai-nilai sosial yang diakui secara konsensus oleh masyarakat itulah yang disebut sebagai identitas bangsa.

Untuk mempertahankan identitas budaya sebagai identitas bangsa maka masyarakat pada umumnya harus mampu bersinergi demi menciptakan demokrasi politik yang sehat, kemandirian ekonomi yang menguntungkan masyarakat, mengutamakan kehidupan sosial budaya, yang sesuai dengan kearifan lokal, serta berperan aktif menjaga keutuhan bangsa terhadap segala ancaman (Saputra, 2017).

\section{JURNAL KEWARGANEGARAAN}


Boteng Tunggul merupakan tradisi yang harus dilestarikan sebagai identitas dari daerah Lombok Timur tepatnya di Desa Pringgasela. Dalam prosesi adat, Boteng Tunggul adalah kain tenun yang diikatkan pada sebuah pohon bambu petung, sehingga tampak seperti umbul-umbul. Berdasarkan data Khafid (2019) kain Tunggul itu dipercaya memiliki nilai sakral tinggi, sehingga ada syarat-syarat khusus yang harus dipenuhi, ketika akan mengibarkan dalam suatu kegiatan adat gawe desa.

Tradisi Boteng Tunggul ini terakhir kali dikibarkan pada tahun 1979 silam, ketika pewaris dari kain ini menikah. Sejak saat itu, masyarakat sudah tidak pernah melihat Tunggul dikibarkan. Boteng Tunggul juga menjadi tradisi yang unik karena tradisi Boteng Tunggul sering digunakan pada upacara adat gawe desa. Saat kain Tunggul dibawa oleh pewaris kemudian diikat di pohon bambu dan Tunggul dikibarkan diiringi dengan seni tradisional sasak yaitu Gendang Belek. Selain itu, benda pusaka ini memiliki nilai magis dan dipercaya dapat menyembuhkan berbagai macam penyakit.

Boteng Tunggul juga merupakan bentuk simbolik yang menghubungkan dengan nilai-nilai ke-Tuhanan Yang Maha Esa. Sekaligus merupakan bentuk syukur kepada Tuhan Yang Maha Esa atas karuniaNya telah memberikan corak warna warni di Kebudayaan Nusa Tenggara Barat (Nurawang, 2019). Akan tetapi, untuk saat ini tradisi Boteng Tunggul pada masyarakat Lombok Timur perlahan mulai mengalami pergeseran. Keadaan ini diwarnai dengan rendahnya pemahaman dan kesadaran masyarakat tentang pentingnya mempertahankan kearifan lokal. Tradisi ini sudah tidak akrab lagi bagi masyarakat dikarenakan sudah tergantikan oleh budaya asing yang lebih praktis. Begitupun dengan kain tenun Tunggul, sedikit dari masyarakat yang paham untuk memanfaatkannya sebagai fashion sesuai dengan kebutuhan zaman. Sekaligus memanfaatkan kain tenun tersebut untuk meningkatkan pertumbuhan ekonomi bagi masyarakat Lombok Timur. Maka dari itu, tradisi ini sangat menarik untuk diteliti lebih dalam. Dikarenakan eksistensinya yang sangat jarang diketahui. Dan ketertarikan untuk melestarikannya sangat jauh dari yang diharapkan.

Berdasarkan hal diatas, perlu sekali adanya sebuah kajian mengenai tradisi Boteng Tunggul sebagai identitas bagi masyarakat Lombok Timur agar tetap mempertahankan keberadaannya di tengah himpitan peradaban yang pesat. Pengembangan pelestarian budaya serta kearifan lokal dapat mengarah pada suatu bidang ilmu yang mengkaji budaya daerah yang terdapat didalam warga negara yaitu civic culture atau budaya kewarganegaraan (Mahardika \& Darmawan, 2016)

Menurut Kymlicka (2015, hal. 114) menyatakan bahwa budaya kewarganegaraan adalah kehidupan sosial sehari-hari yang diwujudkan dalam praktik-praktik meliputi sebagian besar kegiatan manusia. Dalam kehidupan sosial saat ini, agar budaya kewarganegaraan dapat diwujudkan dalam kehidupan sosial sehari-hari maka harus diwujudkan secara institusional baik disekolah, lembaga masyarakat maupun pemerintah. Lebih lanjut, Winataputra (2012, hal. 57) Mengungkapkan bahwa civic culture merupakan budaya yang menopang kewarganegaraan yang berisikan seperangkat ide yang dapat diwujudkan secara efektif dalam representasi kebudayaan untuk tujuan pembentukan identitas warga negara.

Berbicara mengenai civic culture adalah berbicara tentang masyarakat yang menjunjung tinggi nilai kebersamaan dan etika dalam membangun peradaban. Adapun unsur dari budaya kewarganegaraan adalah "civic virtue" atau kebajikan/akhlak kewarganegaraan yang mencakup keterlibatan aktif warganegara (Winataputra \& 
Budimansyah, 2012). Civic culture merupakan suatu usaha untuk mempertahankan eksistensi budaya kewarganegaraan dalam suatu wilayah dengan melibatkan seseorang atau lembaga yang didasarkan atas nilai-nilai pada keterlibatan masyarakat di dalamnya (Almond \& Verba, 1963).

Menurut Wahab \& Sapriya (2011, hal. 33) pendidikan kewarganegaraan akan membentuk warga negara yang mengetahui hak dan kewajiban sebagai warga negara. Bentuk hak dan kewajiban warga negara diluar dari pendidikan formal adalah dengan mempertahankan budaya lokal sebagai identitas dan karakter bangsa. Dalam usaha membangkitkan budaya lokal, PKn dalam usaha pembangunan berkelanjutan adalah PKn yang dapat membentuk warga negara aktif membantu pemerintah. PKn juga berfungsi membantu pemerintah menghadapi tantangan kekinian (Rachman, 2016). Pendidikan kewarganegaraan juga dapat diartikan sebagai pendidikan karakter, etika, moral, yang didalamnya terdapat karakter gotong royong, saling menghormati, dan religius (Hendri, 2020). Pendidikan kewarganegaraan adalah pendidikan yang membentuk sikap kedewasaan manusia dalam melakukan segala tindakan, keputusan kritis dalam segala hal.

Untuk mencari jawaban atas permasalahan yang telah diuraikan diatas. Maka peneliti membuat sebuah rumusan masalah yaitu Bagaimana peran tradisi Boteng Tunggul dalam memperkuat kuat civic culture masyarakat adat Lombok Timur? Penelitian ini nantinya bertujuan untuk menganalisis peran tradisi Boteng Tunggul dalam memperkuat civic culture masyarakat adat Lombok Timur. Sekaligus menjadi acuan untuk memahami nilai-nilai kearifan lokal dalam membangun karakter bangsa.

\section{METODE PENELITIAN}

Penelitian ini menggunakan pendekatan kualitatif dengan menggunakan metode deskriptif. Teknik pengumpulan data dalam penelitian ini menggunakan observasi, wawancara, studi dokumen dan studi literatur. Literatur-literatur yang digunakan ini dijadikan sebagai sumber data utama. Adapun literatur yang digunakan seperti buku, jurnal, makalah, dan hasil penelitian terdahulu yang relevan. Teknik analisis data dilakukan dengan cara reduksi data, display data, verifikasi dan penarikan kesimpulan. Untuk tahap selanjutnya penulis melakukan tahap validitas data. Dengan tujuan untuk menemukan data yang valid, penulis menggunakan teknik triangulasi. Triangulasi merupakan teknik pengecekan data kepada pihak ketiga atau sumber data ketiga, guna meningkatkan peluang riset terhadap temuan itu menjadi lebih kredibel (Ali, 2014).

\section{HASIL DAN PEMBAHASAN}

\section{Tradisi Boteng Tunggul Bagi Masyarakat Adat Lombok Timur}

Tradisi Boteng Tunggul dianggap sebagai cerminan perjalanan tenun masyarakat Pringgasela. Melalui tradisi ini menjadi bagian dan asal usul bahwa masyarakat pringgasela dilahirkan. Boteng Tunggul merupakan bagian dari upacara adat yang didalamnya sering dijadikan sebagai rangkaian pengobatan dan memanjakan sholawat. Keaslian tradisi Boteng Tunggul merupakan identitas masyarakat Lombok dalam mengupayakan kelestarian budaya yang dimilikinya dengan cara mempertahankan nilai-

\section{JURNAL KEWARGANEGARAAN}


nilai seni budaya, nilai tradisional di dalamnya. Peran Boteng Tunggul sudah mampu memberikan kekuatan kepada masyarakat adat Lombok, untuk mempertahankan keaslian budayanya, dengan melakukan prosesi adat secara terus menerus, sebagai bukti penanaman kesadaran pentingnya tradisi Boteng Tunggul.

Maka hal ini sudah sejalan dengan teori kebudayaan yang ditemukan oleh Robert $\mathrm{H}$ Lowie yang mengatakan bahwa kebudayaan merupakan segala sesuatu yang didapatkan dari lingkungan masyarakat. Didalamnya termuat mengenai kepercayaan, adat istiadat, norma yang berlaku serta kemampuan yang diperoleh melalui warisan masa lampau yang diturunkan melalui pendidikan formal dan non formal (Lowie, 1937).

Boteng Tunggul merupakan salah satu budaya yang selalu dipertahankan oleh masyarakat Lombok Timur dalam rangka mengupayakan dan melestarikan kerajinan tenun masyarakat Lombok. Masyarakat Lombok sangat identik dengan kekhasan budaya tenunnya, oleh karena itu Boteng Tunggul merupakan salah satu upaya yang dilakukan oleh masyarakat Lombok agar kekayaan budaya yang mereka miliki tetap terlestarikan secara terus menerus.

Jika dilihat dari peranan tenun dalam Boteng Tunggul, maka peran Boteng Tunggul merupakan peran yang sangat penting dalam melestarikan dan memperkaya budaya masyarakat Lombok. Melalui prosesi adat yang diberikan kepercayaan logis dan spiritual didalamnya. Boteng Tunggul merupakan salah satu usaha yang dilakukan oleh masyarakat Lombok timur untuk mempertahankan keaslian budaya dan melestarikan budaya yang sudah berusia lebih kurang 850 tahun.

Boteng Tunggul salah satu cara yang dilakukan oleh masyarakat adat dalam menciptakan warga negara yang mampu mempertahankan dan melestarikan budayanya. Sehingga secara tidak langsung dalam tradisi Boteng Tunggul ini telah memberikan nilai dan norma tertentu yaitu nilai kearifan lokal di dalamnya yang juga memberikan peran tersendiri dalam lingkungan masyarakat.

Mengingat bahwa prosesi Boteng Tunggul ini merupakan prosesi sakral yang tidak hanya dilakukan oleh satu atau dua individu. Melainkan dilakukan oleh sekolompok besar masyarakat desa. yang terdiri dari keluarga dan organisasi tertentu, maka dalam hal ini usaha mempertahankan keaslian budaya masyarakat Lombok juga memberikan kesan dalam mempertahan persatuan dan kesatuan Indonesia. Melalui tradisi Boteng Tunggul sesuai dengan sila ke 3 dalam Pancasila. Maka pernyataan peneliti ini diperkuat oleh adanya teori Kearifan lokal (local wisdom) Geertz mengatakan bahwa kearifan lokal merupakan usaha manusia untuk mempertahankan entitas yang menentukan harkat dan martabat seorang individu dan kelompoknya (Geertz, 2016).

Sehingga sesuai dengan teori Geertz diatas, kepribadian Warga negara Indonesia khususnya masyarakat Lombok merupakan suatu kesatuan yang sudah hidup dan berkembang dalam jati diri masyarakat Indonesia dan merupakan bagian dari cerminan nilai dan norma masyarakat Indonesia. Oleh karena itu, dalam menciptakan warga negara yang terampil dalam era global juga tidak boleh meninggalkan keaslian warga negara yang cerdas dalam mempertahankan budayanya. Oleh karena itu, perlu adanya penguatan tradisi budaya tertentu yang dapat memperkuat nilai-nilai kebudayaan yang dimiliki oleh masyarakat Indonesia khususnya masyarakat Lombok.

Sehingga tradisi Boteng Tunggul dari banyaknya budaya masyarakat Indonesia khususnya masyarakat Lombok. Menjadi cara yang disepakati bersama oleh masyarakat 
adat untuk mempertahankan kedudukan Boteng Tunggul sebagai warisan dan kekayaan budaya dalam masyarakat adat Lombok. Serta menjadi cara yang dapat ditempuh untuk memperkaya dan memperkuat budaya kewarganegaraan masyarakat adat Lombok. Oleh karena itu, Boteng Tunggul telah mampu berperan sebagai alat untuk memperkuat budaya kewarganegaraan atau civic culture masyarakat Lombok, sehingga hal ini sesuai dengan pernyataan mubah yang mengatakan "masyarakat adat dan pemerintah perlu melakukan peninjauan dalam penyusunan strategi dalam mempertahankan eksistensi budayanya" (Mubah, 2011).

Kemudian, untuk terus menjalankan dan mempertahankan keaslian budaya Boteng Tunggul, berdasarkan hasil analisis peneliti perlu adanya dukungan dan apresiasi dari pemerintah terhadap pelestarian ini. Mengingat bahwa melestarikan budaya merupakan tugas bersama pemerintah dan masyarakat Indonesia, sehingga perlu diperkuat dengan aturan dan kesepakatan bersama untuk tetap melaksanakan, dan melestarikan tradisi Boteng Tunggul. Dan pemerintah bersama masyarakat adat perlu melakukan pola penyaringan budaya asing baik secara menyeluruh agar tidak memberikan pengaruh dalam pelestarian tradisi ini. Hal ini sesuai dengan pendapatnya Paul S.N. tentang parrot pattern dan amoeba pattern dalam usaha melestarikan budaya (Justiani, 2009).

Selain diperlukan dukungan dan apresiasi dari pemerintah, diperlukannya juga peran sekolah sebagai pengemban tugas dan tanggung jawab pelaksana pendidikan. Maka sebagai pemegang tanggung jawab dalam mencerdaskan warga negara yang memiliki karakter budaya. Guru dan sekolah dapat mengupayakan alternatif pelestarian budaya Boteng Tunggul melalui pembelajaran PKn khususnya, misalnya dalam pemberian tugas dan contoh tentang keanekaragaman budaya dalam masyarakat Indonesia. Serta mengaitkannya dengan makna persatuan dan kesatuan oleh adanya keberagaman, atau bahkan sekolah kejuruan dapat mengarahkan kemampuan peserta didik dalam mempelajari tenun. Guna meneruskan kemampuan dalam melestarikan Boteng Tunggul.

Dalam hal ini, sejalan dengan hasil penelitian yang pernah dilakukan oleh $\mathrm{M}$ Chaerul Jamal Munawir. Melakukan penelitian terhadap budaya Boteng Tunggul dan nyongkolan yang merupakan salah satu budaya masyarakat adat Lombok. Tujuan dari penelitian yang dilakukannya adalah untuk meningkatkan kemampuan kongnitif masyarakat Lombok tentang budaya Boteng Tunggul dan nyongkolan serta menjadikannya sebagai bahan ajar di sekolah (Munawir, 2020). Sedangkan penelitian yang dilakukan oleh peneliti ialah meneliti tentang budaya Boteng Tunggul sebagai bagian dari adat istiadat masyarakat Lombok untuk memperkuat kompetensi civic cultural masyarakat adat Lombok. Kedua penelitian ini sama sama membutuhkan kerja sama serta peran yang mendalam dari sekolah, masyarakat adat dan pemerintah dalam melestarikan budaya di wilayah Lombok.

Oleh karena itu, upaya pelestarian Boteng Tunggul merupakan bagian dari usaha masyarakat adat Lombok dalam melestarikan kearifan loka. Tradisi Boteng Tunggul telah mampu memperkuat civic culture masyarakat Lombok, yaitu dengan meningkatnya keterlibatan masyarakat dalam pelaksanaan tradisi Boteng Tunggul. Melibatkan seluruh kalangan masyarakat dalam prosesi adatnya. Sehingga hal ini sesuai dengan teori Almond, yang mengatakan bahwa "setiap individu atau organisasi kelompok tertentu memiliki hak dan kepentingan, untuk terlibat secara langsung dalam melestarikan budaya kewarganegaraannya"(Almond \& Verba, 1963). 
Hasil dari penelitian ini juga menunjukkan bahwa Boteng Tunggul merupakan salah satu dari adat yang dimiliki oleh masyarakat adat Lombok yang masih bertahan. Tradisi ini telah mampu menyatukan dan melibatkan masyarakat secara langsung dalam prosesi adatnya tanpa harus membeda-bedakan status sosial dari masyarakat tersebut. Hal ini sesuai dengan teori local wisdom Geertz yang mengatakan bahwa "untuk terus mempertahankan harkat dan martabat, suatu entitas kelompok atau individu diperlukan usaha yang kompleks dan kerjasama yang baik, antara tokoh-tokoh yang terlibat dalam pelestarian budaya tersebut"'(Geertz, 2016).

Sehingga untuk memperkuat teori local wisdom diatas, peneliti juga sepakat dengan pandangan yang mengatakan bahwa "kearifan lokal merupakan cara yang dilakukan oleh seseorang atau organisasi untuk mempertahankan nilai budaya, keagaman, dan kebiasaan lingkungan masyarakatnya (Ratih \& Suryana, 2020). Oleh karena itu menurut analisis penulis bahwa Boteng Tunggul telah menjadi salah satu budaya yang mampu bertahan dengan eksistensinya dalam menjaga keaslian tradisinya di tengah hiruk pikuk pengaruh globalisasi. Serta membawa dampak dalam pelestarian adat ini, namun Boteng Tunggul telah mampu bertahan dengan kekuatannya bersama dengan masyarakat adat untuk terus melaksanakan adat ini (Nahak, 2019).

\section{Keterlibatan Berbagai Pihak Dalam Melestarikan Tradisi Boteng Tunggul}

Upaya memperkuat civic culture masyarakat adat Lombok Timur, dilakukan dalam kehidupan sehari-hari yaitu bersumber pada pengetahuan budaya yang dimiliki oleh masyarakat adat Lombok. Melalui pelaksanaan tradisi Boteng Tunggul dan kerjasama yang baik dengan masyarakat adat, sekolah dan generasi muda. Apabila pengetahuan tentang keberadaan budayanya sudah diberikan. Maka masyarakat adat dan generasi muda, sudah mampu memposisikan diri dengan tidak menjadikan dirinya sebagai bangsa yang tertinggal oleh peradaban, tetapi bangsa yang maju oleh kekayaan budayanya sendiri. Hal ini sejalan dengan pendapat yang mengatakan bahwa dengan menjaga eksistensi dan nilai kebudayaan yang dapat hidup berdampingan, dengan kehidupan yang modern merupakan keberhasilan daerah, dalam mempertahankan nilai tradisi suatu daerahnya (Hidayat, 2019).

Civic culture merupakan pola perilaku suatu masyarakat dalam lingkungan yang memiliki aspek kebudayaan dan tradisi, yang didalamnya terdapat nilai dan norma yang disepakati bersama dalam lingkungan budaya tersebut (Mahardika \& Darmawan, 2016). Kemudian menjadi aspek yang dihayati dan dilestarikan masyarakat dalam lingkungan hidupnya, serta memberikan kesadaran kepada masyarakat tersebut untuk terus melestarikannya dari generasi ke generasi. Warga negara yang cerdas ialah warga negara yang terampil, memiliki kemampuan dalam melestarikan serta memiliki kesadaran dalam menjaga dan mempertahankannya budayanya.

Melestarikan kebudayaan sudah menjadi kewajiban untuk semua pihak dalam melaksanakannya. Keterlibatan warga negara juga memiliki peranan tersendiri.Warga negara sebagai subjek yang berada di tengah masyarakat dapat memberikan dampak untuk mempromosikan tradisi daerah untuk kembali diperkenalkan kepada generasi muda untuk dapat diwariskan. Untuk pemerintah pusat dapat melakukan sinergitas kepada pemerintah daerah melalui dinas pariwisata dan kebudayaan dalam mewujudkan pembangunan nasional di bidang kebudayaan sebagai upaya mewujudkannya negara 
demokratis yang berkebudayaan. Serta dengan upaya sinergitas tersebut dapat mengembangkan budaya lokal pada domain yang lebih luas lagi.

Menurut Jenks (2017, hal. 80) menyatakan bahwa pendekatan kita terhadap budaya dengan pertama-tama perhatian terhadap betapa pentingnya menumbuhkan kesadaran. Yang menegaskan bahwa kesadaran selalu merupakan kesadaran akan sesuatu. Dengan demikian akan menunjukkan betapa penting kesadaran untuk menumbuh kembangkan budaya. Dari hal ini, untuk membangun kesadaran tidak hanya bertengger pada pengetahuan saja. Akan tetapi butuh dari dalam nurani hingga kesadaran warga negara tumbuh untuk kembali menguatkan budaya lokal yang hampir punah. Makna kebudayaan terbentuk karena status quo dalam sebuah masyarakat. Generasi muda tidak hanya dapat didekati dan dipahami sebagai sasaran nilai namun mereka adalah pembentuk nilai-nilai yang baru. Mereka adalah aktor yang mewarnai dan mendefinisikan budaya dalam ruang yang plural sekaligus multikultural (Anissa, 2015).

Adanya tradisi Boteng Tunggul dapat memperkuat nilai-nilai civic culture pada setiap warga negara. Tradisi Boteng Tunggul merupakan nilai-nilai yang ada dalam masyarakat adat Lombok Timur sebagai warisan nenek moyang yang diwariskan, kepada masyarakat dan generasi muda untuk dijaga, dilestarikan serta dimajukan agar tradisi tersebut tetap ada. Nilai-nilai budaya pada tradisi Boteng Tunggul tentu terdapat nilainilai luhur didalamnya. Hal ini dapat dilihat dari makna dalam setiap kegiatan adat atau upacara-upacara adat yang dilaksanakan pada tradisi tersebut.

Menurut Abdullah (2015, hal. 41) menyatakan bahwa budaya daerah telah memberi kerangka kultural dan memberikan definisi ukuran nilai bagi kehidupan sekelompok orang. Lebih lanjut, budaya daerah menegaskan keberadaannya dalam kehidupan sosial sehingga mengharuskan masyarakat untuk melakukan adaptasi dengan situasi dan perkembangan zaman. Artinya bahwa peran tradisis Boteng Tunggul penting bagi keberlangsungan masyarakat adat Lombok Timur. Masyarakat adat Lombok Timur juga menjadikan penggunaan kain tenun Tunggul dalam kehidupan sehari-hari. Hal ini diyakini dapat menjaga eksistensi dari kain tenun Tunggul tersebut. Pada masyarakat di Provinsi Nusa Tenggara Barat (NTB) kain tenun Tunggul sudah tidak asing lagi. Karena kain tenun tersebut selalu digunakan tidak hanya pada acara-acara adat saja melainkan di kehidupan sehari-hari.

Secara tidak langsung, pelaksanaan tradisi Boteng Tunggul telah mencerminkan nilai-nilai budaya kewarganegaraan atau civic culture. Hanya saja, upaya meningkatkan nilai-nilai tersebut butuh dukungan dari berbagai pihak untuk dapat terealisasikan. Untuk menjadikan budaya sebagai wahana keseharian merupakan tanggung jawab para pemilik budaya tersebut. Seperti masyarakat adat, sekolah, generasi muda, dan teknologi. Kesemuanya harus benar-benar memiliki keterlibatan terhadap tradisi ini, sehingga peran tradisi Boteng Tunggul dapat memperkuat nilai-nilai civic culture. Adapun keterlibatan yang dapat diberikan kepada tradisi Boteng Tunggul dalam memperkuat civic culture sebagai berikut:

\section{Keterlibatan Masyarakat Adat}

Masyarakat adat secara tidak langsung memberikan kontribusi dalam usaha pemerintah dalam melestarikan budaya boteng tunggul. Mengingat bahwa tradisi ini merupakan tradisi turun temurun yang sudah dilakukan oleh masyarakat adat Lombok Timur dari generasi ke generasi. Peran yang melekat pada faktor konsisten yang

\section{JURNAL KEWARGANEGARAAN}


diperankan oleh masyarakat adat akan membawa pengaruh yang baik dalam kelangsungan usaha dalam melestarikan budaya boteng tunggul.

Masyarakat adat merupakan sekelompok masyarakat yang tinggal dalam suatu tatanan kehidupan yang memiliki kekhasan dalam penerapan aktivitas hidupnya. Maka senada dengan Widyanti (2015, hal. 160), Masyarakat adat yang masih mempertahankan nilai kebudayaan daerahnya dikenal dengan sebutan kearifan lokal (local wisdom). Kearifan lokal masih bertahan di tengah-tengah kemajuan zaman yang menghendaki mobilisasi yang serba cepat dan instan serta berupaya menurunkan budaya yang dimilikinya dari generasi ke generasi. Kemudian budaya tersebut tidak dianggap sebagai atau berarti kuno atau terbelakang. Mengingat apa yang tetap dipertahankan tersebut tetap memiliki alasan yang dianggap masuk akal.

Masyarakat adat yang tetap memegang teguh kebudayaan dan tradisi yang dimilikinya tidak selalu bersifat tertutup. Berdasarkan hasil analisis peneliti bahwa mereka dapat secara terbuka menerima komunitas lain seperti pariwisata lokal maupun internasional. Dengan bangga mereka memperkenalkan kekayaan budaya yang dimilikinya, sifat kuat mempertahankan tradisi oleh masyarakat adat Lombok Timur tidak membatasi mereka untuk bersosialisasi dengan yang lainnya. Suatu budaya dan tradisi dapat tergoyahkan keaslian tradisinya, namun masyarakat adat Lombok sudah mampu mempertahankan nilai-nilai budayanya dari sejak jaman nenek moyang sampai sekarang ini (Suparno, Geri Alfikar, Santi, \& Yosi, 2018).

\section{Keterlibatan Sekolah}

Sekolah memiliki keterlibatan untuk mendukung eksistensi tradisi Boteng Tunggul. Sekolah juga dapat menjadi wahana untuk pengembangan karakter. Dalam proses pembelajaran dibutuhkan model pembelajaran berbasis budaya. Agar budaya tetap tumbuh pada setiap peserta didik dan generasi muda. Menurut Komalasari \& Saripudin (2017, hal. 179) menyatakan bahwa model pembelajaran berbasis budaya merupakan strategi belajar yang mengintegrasikan budaya sebagai bahan dari proses pembelajaran. Pembelajaran berbasis budaya dapat dibedakan menjadi tiga macam yaitu, belajar tentang budaya, belajar dengan budaya, belajar melalui budaya.

Belajar tentang budaya, menempatkan budaya sebagai bidang ilmu. Budaya dipelajari dalam satu mata pelajaran tentang budaya. Belajar dengan budaya, terjadi pada saat budaya diperkenalkan sebagai cara atau metode untuk dipelajari. Dalam belajar dengan budaya, budaya dan perwujudannya menjadi media pembelajaran dalam proses belajar. Belajar melalui budaya mengarahkan untuk memperhatikan kedalaman pemikirannya, penjiwaannya terhadap konsep serta imajinasi kreasinya dalam mengekspresikan pemahamannya (Komalasari \& Saripudin, 2017).

Menjaga dan melestarikan kebudayaan yang dimiliki oleh suatu daerah merupakan tugas bersama sebagai warga negara Indonesia, dan hal ini dapat diupayakan dalam dua cara yaitu keterlibatan langsung dalam budaya tersebut dan pengetahuan kewarganegaraan, hal ini seirama dengan pendapatnya (Sendjaja, 2013) yang mengatakan bahwa usaha untuk mempertahankan budaya lokal dapat dilakukan dengan dua cara yaitu culture experience yang merupakan pelestarian budaya yang dilakukan dengan cara langsung seperti terlibat dalam upacara adat, tarian dan lain sebagainya, yang kedua ialah culture knowledge yaitu membuat pusat informasi mengenai fungsi 
dan keberadaan budaya tersebut, serta memberikan edukasi yang baik kepada generasi ke generasi.

Keterlibatan sekolah memiliki peranan penting untuk memelihara budaya lokal. Dengan adanya pembelajaran yang mengarahkan pada basis budaya maka akan dengan mudah untuk melestarikannya. Keterkaitan antara warga negara dan budaya maka porsi mata pelajaran Pendidikan Kewarganegaraan juga harus mengedepankan unsur budaya lokal. Sehingga akan membangun warga negara yang baik sadar dan peduli terhadap budaya lokalnya. Dengan demikian diharapkan muncul karakter yang mengedepankan sikap gotong royong, toleransi, peduli, dan tanggung jawab.

\section{Keterlibatan Generasi Muda}

Pada dasarnya tradisi Boteng Tunggul mampu membuat keterlibatan generasi muda. Akan tetapi belum mampu secara langsung membuat generasi muda sebagai pemern utamanya. Sempitnya ruang yang diberikan untuk pembelajaran budaya secara langsung mejadi sebab utama memudarnya budaya lokal pada generasi muda. Keterlibatan generasi muda pada tradisi ini terfokus pada peran yang dilakukan dalam pelaksanaan tradisi Boteng Tunggul.

Melalui peran generasi muda diharapkan mampu mendorong para pemuda untuk meningkatkan kecintaannya terhadap budaya lokal (Saputra, 2017). Pelestarian tradisi Boteng Tunggul dapat terjadi jika keterlibatan aktif generasi muda yang bergerak untuk memajukan kebudayaannya sendiri. Generasi muda melalui organisasi kepemudaan sangat penting keterlibatannya, dikarenakan organisasi kepemudaan menjadi wadah para generasi muda berhimpun. Dalam realitasnya generasi muda melalui organisasi kepemudaan dapat mendorong generasi muda untuk menciptakan kehidupan sosial budaya yang sesuai dengan kearifan lokal.

Pendayagunaan keterlibatan generasi muda dalam melestarikan tradisi Boteng Tunggul dalam dilaksanakan dengan memberdayakan organisasi kepemudaan setempat. Peran generasi muda dapat dilakukan secara optimal dengan melakukan kegiatankegiatan budaya secara terstruktur dan sistematis. Kegiatan ini diharapkan mampu menjadi cara untuk melestarikan tradisi Boteng Tunggul ini. Rasa kepemilikan telah tumbuh pada generasi muda untuk menjaga dan melestarikan tradisi ini. Kemudian generasi muda dapat memanfaatkan teknologi dan informasi untuk memajukan tradisi ini. Perkembangan zaman tentu harus disikapi dengan baik sehingga bangsa Indonesia tidak tertinggal dari bangsa lain khususnya generasi muda Lombok Timur. Upaya memanfaatkan kecanggihan teknologi dapat dilakukan dengan cara mengabadikan tradisi-tradisi ini kedalam situs budaya.

\section{Pemanfaatan Teknologi}

Memanfaatkan teknologi juga menjadi bagian dalam upaya pelestarian budaya lokal. Pancasila merupakan acuan dalam memanfaatkan kemajuan teknologi sehingga berdampak pada terwujudnya kesejahteraan masyarakat (Fadilah, 2019). Kemajuan teknologi tidak dapat dihindari, namun komitmen sebuah bangsa dalam menyikapinya yang perlu dilakukan. Teknologi telah berkembang dari zaman ke zaman. Perkembangan teknologi saat ini berkembang begitu pesat, maka teknologi menjadi strategi lain dalam melestarikan budaya lokal.

\section{JURNAL KEWARGANEGARAAN}


Untuk memajukan kebudayaan lokal dapat memanfaatkan teknologi di berbagai media atau platform. Penggunaan media sosial dan media online merupakan output dalam memanfaatkan kemajuan teknologi, informasi dan komunikasi, serta menjadi sarana strategis dalam mempromosikan budaya lokal, selain efisiensi juga dapat diakses oleh seluruh masyarakat Indonesia (Nanggala \& Malihah, 2020). Pada praktiknya, masyarakat dan generasi muda berkolaborasi untuk mempromosikan tradisi Boteng Tunggul. Perkembangan teknologi ini memiliki sisi positif bagi pengembangan dan kemajuan budaya lokal. Hal ini ditandai dengan mudahnya mengakses berbagai platform untuk publikasi di media sosial.

Perkembangan teknologi harus benar-benar dimanfaatkan secara bijak untuk kebutuhan pemajuan kebudayaan. Penggunaan media sangat bermanfaat untuk menyimpan data mengenai tradisi lokal sebagai upaya menjaga keutuhan informasi bagi generasi muda selanjutnya. Perlunya menjaga serta mewarisi informasi kebudayaan sebagai sarana memberikan edukasi serta menggerakkan hati masyarakat agar berkenan melestarikan kebudayaan yang dimaksudkan (Priatna, 2017).

\section{Tantangan Memperkuat Civic Culture Melalui Tradisi Boteng Tunggul}

Masalah pelestarian tradisi di tengah perubahan zaman yang begitu signifikan tidaklah mudah. Perubahan yang begitu cepat mengakibatkan terjadinya perubahan pada sektor kebudayaan. Masalah pelestarian dan perubahan bukanlah sesuatu yang bersifat mutlak. Artinya bahwa kebudayaan apapun mau tidak mau pasti akan mengalami perubahan dari keadaan aslinya. Hal ini biasanya dipicu oleh munculnya perkembangan zaman yang menghampiri dengan perubahan atau unsur dinamis didalamnya (Prayogi \& Danial, 2016). Maka tantangan inilah yang perlu diperhatikan masyarakat dalam menjaga dan melestarikan kearifan lokalnya.

Tantangan yang dihadapi oleh masyarakat Lombok dalam mempertahankan tradisi budaya Boteng Tunggul ialah kondisi kemajuan budaya yang berkaitan dengan globalisasi. Dapat memberikan pengaruh dan kegoyahan dalam pelestarian budaya Boteng Tunggul. Dewasa ini, tentu saja sasaran utamanya adalah generasi muda yang didalam dirinya dan kehidupan sehari-harinya sudah memudar budaya kewarganegaraan atau civic culture. Tantangan ini menjadi salah satu faktor dalam mempertahankan tradisi Boteng Tunggul karena akan mempengaruhi minat dalam prosesi pelaksanaan adat Boteng Tunggul. Teori Geertz mengatakan bahwa "kekuatan kearifan lokal yang melekat pada diri individu atau kelompok, adalah ditentukan oleh bagaimana usaha individu atau kelompok tersebut menjaga eksistensi budaya yang dimilikinya, agar terjaga harkat dan martabat entitas dirinya" (Geertz, 2016).

Kemudian tantangan lain yang ditemukan dalam penelitian ini ialah implementasi pelestarian tradisi Boteng Tunggul. Di sekolah, belum mampu diterapkan dengan baik dalam lingkungan sehari-hari, sehingga menjadi salah satu faktor penghambat dalam memperkuat civic culture dalam masyarakat Lombok. Oleh karena itu Tylor mengatakan bahwa "agar warga negara memiliki budaya kewarganegaraan yang kompleks di dalamnya harus termuat pengetahuan dan keilmuan serta mampu melestarikan dalam kehidupan sehari-hari (Tylor, 2018). Dan hal ini sejalan dengan pendapatnya Almond dan Ferdinand dalam teorinya yang menyatakan bahwa "untuk memperkuat civic culture nya, suatu individu perlu diberikan kesempatan untuk berpartisipasi secara langsung untuk terciptanya warga negara yang berbudaya" (Almond, Gabriel \& Verba, 2017). 
Pendidikan harus menyentuh wahana sosio-kultural salah satunya dengan memanfaatkan pendidikan berbasis kearifan lokal. Membangun pendidikan yang berbasis kearifan lokal mengandung nilai yang relevan dan berguna untuk pendidikan, serta dapat dilakukan dengan cara merevitalisasi budaya lokal (Tamura, 2018). Jalur pendidikan merupakan langkah yang tepat untuk membaangun karakter bangsa berbasis pada budaya lokal. Penanaman karakter tidak akan berhasil jika hanya dengan transfer ilmu saja, butuh keteladanan untuk membentuk karakter yang melibatkan semua unsur pendidikan. Serta andil dan partisipasi dari semua stakeholder pendidikan untuk memberikan kontribusi nyata akan pelestarian budaya lokal.

Pendidikan yang berbasis pada budaya lokal akan mempersiapkan generasi muda agar lebih siap dalam menghadapi perubahan zaman. Pendidikan berbasis pada budaya lokal akan lebih mudah diterima di masyarakat dengan budaya sebagai pilar pendidikan. Sehingga karakter yang diharapkan akan muncul dan tertanam dengan baik. Dengan demikian, seluruh elemen pendidikan turut andil sebagai pelaku budaya lokal dalam menginternalisasikan nilai-nilai budaya daerah untuk membentuk suatu model pendidikan karakter yang khas bagi setiap daerah. Selanjutnya, jika dilihat era globalisasi dalam kemajuan yang sangat pesat akan merubah pola pikir dan cara hidup masyarakat. Terus-menerus akan menyesuaikan dengan kebutuhan dan kemajuan jaman. Sehingga akan berkembang pemikiran bahwa pelaksanaan tradisi adat merupakan sesuatu yang bersifat kolot dan tidak modernisasi. Maka pola pikir dan cara hidup tersebut dapat menggeserkan nilai budaya yang dimiliki oleh masyarakat, sehingga kebanyakan warga negara atau generasi muda enggan untuk berpartisipasi langsung dalam urusan kebudayaan daerah setempat.

Tantangan lain dalam meningkatkan civic culture melalui tradisi Boteng Tunggul Salah satunya adalah dengan mendayagunakan kain tenun Tunggul sebagai bentuk fashion sesuai dengan kebutuhan zaman. Lemahnya masyarakat dalam memanfaatkan keadaan zaman untuk memajukan kearifan lokal menjadi penghambat kearifan lokal itu untuk maju dan berkembang. Jika kain tenun Tunggul dapat diberdayakan untuk kemajuan zaman, Hal ini tentu akan menyadarkan generasi muda untuk terlibat aktif dalam upaya melestarikan tradisinya. Dengan demikian, jika tradisi dimodifikasi sesuai dengan kebutuhan zaman, maka secara tidak langsung akan membangkitkan gairah putraputra daerah untuk terus mempromosikan tradisinya. Dengan begitu, tradisi ini akan dikenal sampai ke generasi berikutnya.

Mengingat masyarakat Lombok Timur masih ada yang berprofesi sebagai penenun Kain Tunggul. Kain tenun Tunggul masih menjadi ciri khas bagi masyarakat Lombok. Kain tenun ini memiliki nilai-nilai kebudayaan yang tidak bisa lepas dari tradisi Boteng Tunggul. Menjadi sebuah kesatuan dan tidak dapat terpisahkan. Secara tidak langsung dalam prosesi adat Boteng Tunggul masyarakat adat Lombok Timur telah mengajarkan nilai-nilai civic culture.

Menurut analisis peneliti bahwa indikator civic culture ialah jika manusia mampu berpartisipasi secara langsung dalam urusan di lingkungan sekitarnya. Menurut Geertz dalam bukunya interpretation culture bahwa suatu kebudayaan itu dipandang dengan suatu pendekatan bersifat teks yang mengarahkan pada konsep kebudayaan yang simbolik. Serta kebudayaan tersebut dapat dibaca, ditranslasikan serta mampu diimplementasikan dengan baik dalam lingkungannya (Geertz, 2016) 
Kemudian hasil penelitian dalam pembahasan ini menunjukkan bahwa peran Boteng Tunggul telah mampu menjawab tantangan-tantangan di atas, dengan segala upaya yang sudah dilakukan oleh elemen atau pihak-pihak yang berhubungan dengan pelestarian tradisi Boteng Tunggul. Tradisi ini dianggap telah mampu melalui tantangan tersebut dengan memperkuat civic culture masyarakat Lombok melalui kerjasama pihak sekolah, kelompok masyarakat adat dan pemerintah daerah. Hal ini sesuai dengan hasil penelitian yang dilakukan oleh Ali Syahbani tentang Implementasi budaya. Dalam menumbuhkan sikap afektif pada budaya begibung di Lombok.

Hasil penelitian oleh Ali Syahbani menunjukkan bahwa untuk menumbuhkan sikap afektif pada budaya begibung pada masyarakat Lombok perlu adanya jalinan kerjasama yang baik antara masyarakat adat dengan sekolah seperti menjadikan bahan ajar di sekolah kemudian tidak lupa dukungan dari pemerintahan setempat agar budaya ini tetap terlaksana sampai generasi berikutnya. Maka sesuai dengan teori Almond tentang civic culture yang mengatakan bahwa untuk mempertahankan eksistensi budaya kewarganegaraan suatu daerah perlu adanya usaha atau tindakan seseorang dan lembaga yang didasarkan atas nilai-nilai yang menekankan pada keterlibatan masyarakat (Almond, Gabriel \& Verba, 2017).

\section{Tradisi Boteng Tunggul dalam Memperkuat Civic Culture}

Kearifan lokal butuh untuk terus menerus diwariskan, maka sangat diperlukan sekali peranan masyarakat dan lembaga adat, untuk memberikan pembelajaran kepada generasi muda untuk sadar terhadap adat istiadat (Nurdin, 2013). Kebudayaan lokal untuk menjaga agar tidak termakan oleh zaman dan tergantikan oleh budaya asing. Dengan adanya budaya lokal yang mampu menopang kehidupan warga daerah sekaligus telah membentuk identitas warganya. Maka budaya kewarganegaraan telah tumbuh didalamnya (Malatuny \& Ritiauw, 2018).

Menurut Denny (dalam Islamuddin 2016, hal. 58) menyatakan bahwa civic culture digunakan sebagai label untuk merangkum sebagai nilai dan perilaku yang memperkokoh institusi demokrasi. Elemen civic culture antara lain, penghormatan atas kultur, kemampuan bekerja sama, dan sikap saling percaya dalam interaksi sosial. Dalam konteks civic culture, melestarikan budaya itu ditandai dengan adanya sikap warga negara untuk tetap saling percaya, bekerja sama, tanggung jawab dan gotong royong (Mauludea, Nurhadianto, \& Islamuddin, 2016).

Dalam tradisi Boteng Tunggul, prosesi adat yang diberikan memiliki kepercayaan logis dan spiritual didalamnya. Pada pelaksanaannya, tradisi ini dijalankan secara bersama-sama dan saling mempercayai satu sama lain. Boteng Tunggul juga merupakan bentuk simbolik yang menghubungkan dengan nilai-nilai ke-Tuhanan Yang Maha Esa sekaligus merupakan bentuk syukur kepada Tuhan Yang Maha Esa atas karuniaNya telah memberikan corak warna warni di Kebudayaan Nusa Tenggara Barat. Boteng Tunggul merupakan bagian dari upacara adat yang di dalamnya sering dijadikan sebagai rangkaian pengobatan dan memanjatkan sholawat.

Dalam konteks civic culture, tradisi Boteng Tunggul pada masyarakat adat Lombok Timur memiliki nilai-nilai yang ditandai dengan munculnya karakter warga negara untuk menghargai budaya dengan tetap mempertahankannya, munculnya nilai religius, gotong royong, dan tanggung jawab. Dalam civic culture (budaya kewarganegaraan) akan mengarahkan budaya untuk disikapi oleh warga negara dengan memunculkan sikap untuk 
saling menghargai, tanggung jawab, kebersamaan, untuk mengembangakn nilai-nilai kearifan lokal sebagai identitas (Feriandi, 2017).

Karakter itu muncul seiring dengan kuatnya tradisi Boteng Tunggul di masyarakat adat untuk tetap ada ditengah-tengah kehidupan mereka. Tradisi Boteng Tunggul telah membangun karakter religius, gotong royong dan tanggung jawab di masyarakat. Serta memunculkan nilai-nilai kebersamaan dan komitmen yang kuat bagi masyarakat Lombok Timur. Hal ini tentu akan menjadi faktor penting dalam meningkatkan budaya kewarganegaraan atau civic culture. Boteng Tunggul sudah menjadi identitas pada masyarakat Lombok Timur maka melestarikan tradisi ini sudah menjadi kewajiban bagi masyarakat Lombok Timur. Dalam upaya meningkatkan civic culture masyarakat dapat membentuk tradisi dikembangkan sesuai dengan perkembangan zaman agar tidak luntur termakan waktu. Seluruh masyarakat dapat bekerjasama demi menghidupkan kembali tradisi ini. Keterkaitan antara tradisi Boteng Tunggul dengan nilai-nilai civic culture memiliki arsirannya.

Apabila berkaca pada teori civic culture, tradisi ini telah menopang kehidupan masyarakat Lombok Timur sehingga mampu membentuk identitas warganya. Disisi lain ketika tradisi ini dilaksanakan maka akan terlihat sisi Ke-Indonesia-an yang hidup. Kehidupan berbangsa dan bernegara terjalin kental dan harmonis dalam pelaksanaan tradisi ini. Terjaganya tradisi Boteng Tunggul diperlukan agar tujuan dari nilai-nilai yang terdapat dalam budaya masyarakat tidak hilang. Tradisi Boteng Tunggul telah mencerminkan nilai-nilai luhur yang sama dengan nilai-nilai luhur Pancasila.

Menurut Winataputra \& Budimansyah (2012, hal. 62) bahwa unsur dari budaya kewarganegaraan adalah civic virtue atau kebajikan kewarganegaraan. Yang didalamnya mencakup keterlibatan aktif warga negara, hubungan kesejajaran/egaliter, saling percaya, dan toleran, kehidupan yang kooperatif, serta semangat kemasyarakatan. Tradisi Boteng Tunggul kaitannya dengan memperkuat civic culture telah membangun kesadaran warga negara untuk terlibat aktif dalam pelestarian budaya lokal yang hampir punah. Pemahaman ini akan membentuk warga negara yang baik serta mencerminkan nilai-nilai civic culture.

Peran tradisi Boteng Tunggul dapat menjadikan masyarakat Lombok Tmur sebagai warga negara yang baik dan mencerminkan nilai-nilai civic culture, serta memiliki pemahaman yang baik dalam mengelola budaya lokal. Budaya lokal dapat juga dijadikan sarana pengembangan kepribadian masyarakat Lombok Timur untuk menjunjung tinggi budaya ketimuran serta mengimplementasikan nilai-nilai Pancasila. Hak ini menjadi faktor penting dalam meningkatkan budaya kewarganegaraan bagi masyarakat Lombok Timur.

Penelitian ini memberikan sisi lain dalam budaya lokal dan nilai-nilai civic culture. Penelitian ini tentu berbeda dengan penelitian sebelumnya. Peneliti menemukan bahwa ada keterkaitan antara tradisi Boteng Tunggul dengan nilai civic culture. Dalam hal ini, tradisi Boteng Tunggul mampu memberikan peran signifikan dalam memperkuat nilainilai civic culture pada masyarakat adat Lombok Timur. Dengan demikian, konsepsi tersebut telah menginternalisasikan civic culture ke dalam tradisi Boteng Tunggul.

Melalui penelitian ini dapat mentransformasikan nilai civic culture dalam tradisi Boteng Tunggul. Selanjutnya memberikan kontruksi nilai civic culture dalam tradisi Boteng Tunggul untuk memperkuat nilai civic culture masyarakat adat Lombok. 
Penelitian ini juga menyajikan konsep civic culture dalam tradisi Boteng Tunggul sekaligus menjadi sarana untuk memperdalam dan memperluas nilai civic culture dalam tradisi Boteng Tunggul dan memperkuat budaya kewarganegaraan masyarakat adat Lombok.

\section{SIMPULAN}

Tradisi Boteng Tunggul pada masyarakat Lombok Timur memiliki nilai kebersamaan, nilai gotong royong, toleran yang secara kooperatif menguatkan civic culture di masyarakat Lombok Timur. Peran serta seluruh elemen baik pemerintah, masyarakat, maupun lembaga adat. Sinergitas perlu dilakukan guna melestarikan tradisi upacara adat Boteng Tunggul, agar terjaga keaslian dari nilai-nilai budaya dalam pelaksanaan tradisi adat Boteng Tunggul. Dampak yang dapat diberikan dari penelitian ini. Pertama, akan memberikan dampak terhadap pendidikan kewarganegaraan di masyarakat untuk memajukan dan melestarikan budaya lokal sebagai bagian dari kehidupan sehari-hari. Kedua, memberikan dampak terhadap mata pelajaran pendidikan kewarganegaraan di setiap jenjang pendidikan untuk memasukkan unsur budaya lokal sebagai materi pokok yang harus dipelajari oleh seluruh peserta didik. Agar kearifan lokal itu tetap terjaga selamanya.

Dari penelitian ini dapat diharapkan memberikan rekomendasi kepada berbagai pihak untuk menguatkan kembali sektor kebudayaan sebagai upaya memajukan tradisi yang hampir hilang. Dalam upaya melestarikan tradisi ini, keluarga, masyarakat serta pemerintah melakukan kerjasama dalam menanamkan pengetahuan urgensi pelestarian tradisi adat kepada masyarakat khususnya kepada generasi-generasi muda, keluarga dapat mengambil peran utama dengan memberikan pengetahuan melalui pendidikan budaya dalam lingkungan keluarga, kemudian sekolah dapat menjalankan misinya sebagai pelaku utama dalam pendidikan dengan merangkaikan pembelajaran yang bernuansa pelestarian budaya mengenai tradisi ini, kemudian pemerintah dan masyarakat adat dapat bersamasama mepertahankan keaslian tradisi Boteng Tunggul dengan terus melakukannya.

\section{UCAPAN TERIMA KASIH}

Rasa syukur sedalam-dalamnya kami haturkan kepada sang pemilik alam semesta yaitu Allah SWT, Dzat yang maha pengasih dan maha penyayang. Yang telah memberikan kepada hambaNya kepuasan nikmat tiada batas. Dan tempat kembali bagi seluruh insan yang merindukannya. Tak lupa pula, salam dan taslim kepada baginda Rasulullah SAW, fenomena alam yang tampak sempurna, semoga kita termasuk kedalam golongan umatnya di akhir zaman kelak. Ucapan terima kasih ini kami sampaikan kepada seluruh pihak yang telah membantu kami dalam menyelesaikan penelitian ini. Semoga berkat bantuan berbagai pihak, penelitian ini dapat bermanfaat bagi semua kalangan baik pemerintah, akademisi, generasi muda serta masyarakat.

\section{DAFTAR PUSTAKA}

Abdullah, I. (2015). Konstruksi dan Reproduksi Kebudayaan. Yogyakarta: Pustaka Pelajar. 
Ali, M. (2014). Memahami Riset Prilaku dan Sosial. Jakarta: Bumi Aksara.

Almond, G. A., \& Verba, S. (1963). The Civic Culture: Political Attitude and Democracy in Five Nations. Boston: Little, Brown and Company.

Anissa, F. (2015). Civic of Culture: Media, Kaum Muda, dan Mengenali Ke-Istimewaan Yogyakarta. Komunikator, 7(1), 1-18.

Fadilah, N. (2019). Tantangan dan Penguatan Ideologi Pancasila dalam Menghadapi Era Revolusi Industri 4.0. Journal of Digital Education, Communication, and Arts (DECA), 2(02), 66-78. https://doi.org/10.30871/deca.v2i02.1546

Feriandi, Y. A. (2017). Revitalisasi Moral Kewarganegaraan dalam Ungkapan Jawa Sebagai Sumber Pembentukan Civic Culture dan Politic Culture. Jurnal Civics: Media Kajian Kewarganegaraan, 14(2), 176-182. https://doi.org/10.21831/civics.v14i2.15323

Geertz, C. (2016). Islam Observed Religious Development in Marocco and Indonesia. United States of America: Phoenix Editio.

Hendri. (2020). Penguatan Pendidikan Kewarganegaraan Melalui Pendidikan Pesantren dalam Membentuk Keadaban Moral Santri. Jurnal Kewarganegaraan, 17(1), 35. https://doi.org/10.24114/jk.v17i1.18702

Hidayat, O. T. (2019). Pembinaan Budaya Kewarganegaraan (Civic Culture) Melalui Nilai-Nilai Kearifan Lokal Sunda. SOSIETAS, 9(1).

Jenks, C. (2017). Culture: Studi Kebudayaan (E. Setyawati, Penerj.). Yogyakarta: Pustaka Pelajar.

Justiani. (2009). Globalisasi dan Nasionalisme Indonesia. Surabaya: Surabaya Post.

Khafid, S. (2019). Boteng Tunggul, Tradisi Ratusan Abad dari Desa Pringgasela. Diambil 10 Januari 2021, dari travel.tempo.co website: https://travel.tempo.co/read/1249114/boteng-tunggul-tradisi-ratusan-abad-daridesa-pringgasela/full\&view $=$ ok

Komalasari, K., \& Saripudin, D. (2017). Pendidikan Karakter Konsep dan Aplikasi Living Value Education. Bandung: Refika Aditama.

Kymlicka, W. (2015). Kewargaan Multikultural. Jakarta: LP3ES.

Lowie, R. H. (1937). The History of Ethnological Theory. New York: Rinehart \& Company. Inc.

Mahardika, I. W. T., \& Darmawan, C. (2016). Civic Culture dalam Nilai-Nilai Budaya dan Kearifan Lokal Masyarakat Bali Aga Desa Trunyan. Humanika, 23(1), 20-31. https://doi.org/10.14710/humanika.23.1.20-31

Malatuny, Y. G., \& Ritiauw, S. P. (2018). Eksistensi Pela Gandong Sebagai Civic Culture Dalam Menjaga Harmonisasi Masyarakat Di Maluku. Sosio Didaktika: Social Science Education Journal, 5(2), 35-46. https://doi.org/10.15408/sd.v5i2.10554

Mauludea, H., Nurhadianto, \& Islamuddin. (2016). Budaya Masyarakat Suku Talang Mamak dalam Bagian Civic Culture. Edukasi: Jurnal Pendidikan, 14(1), 53-68. https://doi.org/10.31571/edukasi.v14i1.285 
Mubah, A. S. (2011). Strategi Meningkatkan Daya Tahan Budaya Lokal dalam Menghadapi Arus Globalisasi. Jurnal Unair, 24(4), 302-308.

Munawir, M. C. J. (2020). Nilai Edukatif Dalam Budaya Lombok Nyongkolan. Jurnal Seni dan Pendidikan Seni, Universitas Negeri Yogyakarta, 18(1), 42-50. https://doi.org/10.21831/imaji.v18i1.31643

Nahak, H. M. . (2019). Upaya Melestarikan Budaya Indonesia di Era Globalisasi. Jurnal Sosiologi Nusantara, 5(1), 65-76. https://doi.org/10.33369/jsn.5.1.65-76

Nanggala, A., \& Malihah, E. (2020). Peran Tradisi Irung-Irung dalam Memperkuat Civic Engagement Generasi Muda di Kabupaten Bandung Barat. Jurnal Ilmiah Pendidikan Pancasila dan Kewarganegaraan, 5(1), 1. https://doi.org/10.17977/um019v5i1p1-16

Nurawang, R. (2019). Tradisi Tenun Boteng Tunggul Masyarakat Lombok Timur. Diambil 11 Januari 2021, dari daerah.sindonews.com website: https://daerah.sindonews.com/berita/1439489/29/tradisi-tenun-boteng-tunggulmasyarakat-lombok-timur?showpage $=$ all

Nurdin, A. (2013). Revitalisasi Kearifan Lokal di Aceh: Peran Budaya dalam Menyelesaikan Konflik Masyarakat. Analisis: Jurnal Studi Keislaman, 13(1), 135154. https://doi.org/10.24042/ajsk.v13i1.645

Panjaitan, L. M., \& Sundawa, D. (2016). Pelestarian Nilai-Nilai Civic Culture dalam Memperkuat Identitas Budaya Masyarakat: Makna Simbolik Ulos dalam Pelaksanaan Perkawinan Masyarakat Batak Toba di Sitorang. Journal of Urban Society's Arts, 3(2), 64-72. https://doi.org/10.24821/jousa.v3i2.1481

Prayogi, R., \& Danial, E. (2016). Pergeseran Nilai-Nilai Budaya Pada Suku Bonai Sebagai Civic Culture di Kecamatan Bonai Darussalam Kabupaten Rokan Hulu Provinsi Riau. Humanika, 23(1), 61. https://doi.org/10.14710/humanika.23.1.61-79

Priatna, Y. (2017). Melek Informasi Sebagai Kunci Keberhasilan Pelestarian Budaya Lokal. Publication Library and Information Science, 1(2), 37. https://doi.org/10.24269/pls.v1i2.720

Rachman, F. (2016). Pendidikan Kewarganegaraan dalam Pembangunan Berkelanjutan dan Tantangan Ketegangan. In B. Mulyono, M. Murdiono, Halili, I. Arpanudin, \& Suyato (Ed.), Prosiding Konferensi Nasional Kewarganegaraan Ke-2: Penguatan Kajian Atas Isu-Isu Aktual Kewarganegaraan dalam Konteks Kependidikan dan Non-Kependidikan (hal. 209-236). Yogyakarta: Laboratorium PKn FIS UNY.

Ratih, D., \& Suryana, A. (2020). Nilai-Nilai Kearifan Lokal Leuweung Gede Kampung Kuta Ciamis dalam Mengembangkan Green Bihavior Untuk Meningkatkan Karakter Mahasiswa. Jurnal Artefak, 7(2), 141-152. https://doi.org/10.25157/ja.v7i2.4199

Saputra, I. (2017). Peran Organisasi Kepemudaan dalam Meningkatkan Pemahaman Wawasan Nusantara di Kalangan Pemuda Indonesia. Civic-Culture: Jurnal Ilmu Pendidikan PKn dan Sosial Budaya", 1(1), 33-41.

Sendjaja, S. D. (2013). Teori Komunikasi. Jakarta: Universitas Terbuka. 
Suneki, S. (2012). Dampak Globalisasi Terhadap Eksistensi Budaya Daerah. Jurnal Ilmiah Civicus, II(1), 307-321. https://doi.org/10.32787/ijir.v3i1.88

Suparno, Geri Alfikar, Santi, D., \& Yosi, V. (2018). Mempertahankan Eksistensi Budaya Lokal Nusantara Ditengah Arus Globalisasi Melalui Pelestarian Tradisi Gawai Dayak Sintang. Jurnal Pekan: Jurnal Pendidikan Kewarganegaraan, 3(1), 43-56. https://doi.org/10.31932/jpk.v3i1.144

Tamura, H. (2018). Penerapan Pendidikan Berbasis Kearifan Lokal di SD Negeri 8 Rambutan Kabupaten Banyuasin Menuju Global Citizen. Journal of Chemical Information and Modeling, 53(9), 287.

Tylor, E. B. (2018). Primitive Culture; Part 1: The Origins of Culture. London: Murray. Undang-Undang Dasar Negara Republik Indonesia Tahun 1945.

Wahab, A. A., \& Sapriya. (2011). Teori dan Landasan Pendidikan Kewarganeraan. Bandung: Alfabeta.

Widyanti, T. (2015). Penerapan Nilai-Nilai Kearifan Lokal dam Budaya Masyarakat Kampung Adat Cireundeu Sebagai Sumber Pembelajaran IPS. Pendidikan Ilmu Sosial, 24(2), 157-162. https://doi.org/10.17509/jpis.v24i2.1452

Winataputra, U. S., \& Budimansyah, D. (2012). Pendidikan Kewarganegaraan dalam Perspektif Internasional (Konteks, Teori, dan Profil Pembelajaran). Bandung: Widya Aksara Press. 